\title{
META ANALISIS ASSESSMEN FORMATIF DI PENDIDIKAN TINGGI
}

\author{
Molli Wahyuni \\ Universitas Pahlawan Tuanku Tambusai, Jl. Tuanku Tambusai \\ whykpr@gmail.com
}

\begin{abstract}
This study aims to determine the application of formative assessments in universities. The application is seen in the results of the previous 15 journals studies involved in this meta-analysis. Meta-analysis is a review of a number of research results in similar problems. The unit of analysis in this study are written documents on formative assessment, and this research report is taken by purposive sampling, that is based on suitability of research theme. The main instrument of research is penelti own assisted with pantuan researcher. The data analysis used is quantitative data analysis with percentage and qualitative data analysis for the data of narrative study of the researches encountered. The results show that formative assessment in higher education has an important role in evaluating student performance
\end{abstract}

\section{Keywords: Formative Assessment Analysis}

\begin{abstract}
Abstrak
Penelitian ini bertujuan untuk mengetahui penerapan assessmen formatif di perguruan tinggi. Penerapan tersebut dilihat pada hasil penelitian 15 jurnal terdahulu yang dilibatkan dalam meta analisis ini. Meta analisis merupakan kajian atas sejumlah hasil penelitian dalam masalah sejenis. Unit analisis dalam penelitian ini adalah dokumen-dokumen tertulis tentang asesmen formatif, dan laporan penelitian ini diambil secara purposive sampling, yakni berdasarkan kesesuaian tema penelitian. Instrumen utama penelitian adalah penelti sendiri dibantu dengan bantuan peneliti. Analisis data yang digunakan adalah analisis data kuantitatif dengan persentase dan analisis data kualitatif untuk data-data asil kajian naratif terhadap penelitianpenelitian yang ditemui. Hasil penelitian menunjukkan bahwa asesmen formatif di pendidikan tinggi memiliki peran penting dalam mengevaluasi kinerja mahasiswa.
\end{abstract}

Kata kunci: Analisis asesmen formatif

Asesmen pada pembelajaran adalah proses pengumpulan informasi untuk memantau kemajuan belajar mahasiswa, mencari cara terbaik untuk memfasilitasi belajar mahasiswa, dan mengambil keputusan tentang perkembangan dan pencapaian (hasil) belajar mahasiswa. Assessmen merupakan salah satu tahapan yang dilaksanakan dalam pembelajaran. Assessmen dilakukan untuk mengetahui bagaimana kemampuan siswa dalam pembelajaran. Knight (2006) mengungkapkan bahwa assessmen adalah tentang membuat penilaian mengenai kualitas kinerja siswa. Centre for Educational Research and Innovation (CERI) (2008) mengatakan bahwa assesmen merupakan suatu yang vital dalam proses pendidikan.

Asesmen merupakan salah satu tahapan penting dalam pembelajaran. Gikandi (2011) menyebutkan bahwa asesmen merupakan jantung dari pendidikan tinggi formal. Gikandi juga mengutip pernyataan Bransford dan Cocking (2000) yang menyebutkan bahwa asesmen merupakan komponen inti untuk pembelajaran yang efektif. Tujuan asesmen pembelajaran mahasiswa yaitu memantau kemajuan belajar mahasiswa, memantau efektivitas perkuliahan, mengetahui pencapaian hasil belajar dan memberi nilai mahasiswa. The fundamental purpose of assessment is to establish 
where learners are in their learning at the time of assessment, that is, what they know, understand, and can do. Masters (2014).

Secara umum asesmen yang dapat dilakukan terhadap siswa yaitu asesmen formatif dan asesmen sumatif. Asesmen sumatif untuk merangkum prestasi siswa dalam rangka memberikan semacam sertifikasi, sedangkan asessmen formatif memberi umpan balik kepada siswa untuk mendukung pembelajaran (penilaian (Falchikov 2005; Sadler 1989; Yorke 2003). Kedua tujuan penilaian saling terkait erat, dan berlaku untuk sebagian besar tugas penilaian, meskipun memiliki batas tertentu (Boud 2000). Untuk melihat bagaimana penelitian tentang penerapan asesmen formatif di pendidikan tinggi, pada paper ini dilakukan meta analisis tentang asesmen formatif di pendidikan tinggi dari berbagai hasil penelitian terdahulu.

Asesman formatif didefinisikan sebagai kegiatan penilaian mengenai kualitas prestasi siswa, dan dimana informasi ini digunakan untuk memfasilitasi pembelajaran siswa (Black and Wiliam, 1998), dikutip oleh Charty (2017). Yorke (2003) mengungkapkan bahwa asesmen formatif merupakan konsep yang lebih kompleks daripada yang mungkin tampak pada pandangan pertama. Penilaian formatif formal dapat didefinisikan sebagai yang itu berlangsung dengan mengacu pada kerangka penilaian kurikuler tertentu.

Cruz, et.al (2011) mengatakan bahwa asesmen merupakan suatu bagian penting tentang bagaimana orang belajar, karena asesmen formatif itu memungkinkan peserta didik untuk menilai kemajuan mereka sendiri melalui materi dan teknik praktek yang relevan. Asesmen formatif dianggap sebagai pendekatan yang menjanjikan untuk memperbaiki pengajaran dan pembelajaran (Rakoczy, 2017). Tujuan utama asesmen formatif adalah memberi kontribusi pada pembelajaran siswa melalui penyediaan informasi tentang kinerja (Yorke, 2003). Dari beberapa pendapat ahli tersebut dapat disimpulkan bahwa asesmen formatif merupakan asesmen yang dilakukan selama proses pembelajaran dan bermanfaat untuk meningkatkan kualitas pembelajaran.

Keefektifan asesmen formatif di perguruan tinggi bergantung pada kehadiran setidaknya fitur yang tercantum pada Tabel 1. Fitur ini dapat dilihat sebagai bentuk garis besar dari teori penilaian formatif. (Yorke, 2003).

Tabel 1. Features a Theory of Effective Formative Assesment

\begin{tabular}{ll}
\hline 1 & Assesor are aware of \\
& a. The epistemology of discipline \\
b. Stages of student's intellectual and moral development \\
c. The individual student's knowledge and stage of intellectual development \\
d. The psychology of giving and receiving feedback
\end{tabular}


Kowalski (2009) dalam penelitiannya mengungkapkan tentang penggunaan tekonologi dalam melakukan asesmen formatif, salah satunya yakni menggunakan tablet PCs. Asesmen yang menggunakan teknologi dikatakan menarik karena merupakan asesmen formatif dalam real-time mahasiswa. Sharma, et.al (2015) mengungkapkan bahwa dalam pendidikan kedokteran, asesmen formatif merupakan salah satu faktor terpenting yang sangat menentukan dalam merevolusi proses pembelajaran mahasiswa.

Friedrich-Nel adn Kinnon (2015) menyimpulkan pernyataan peneliti LaPidus (997), Hugo( 2009) dan Bak (2011) bahwa di perguruan tinggi, tujuan asesmen formatif pascasarjana adalah untuk mempersiapkan siswa tidak hanya untuk penerimaan tesis atau disertasi yang berhasil, namun dalam konteks yang lebih luas untuk mempersiapkan siswa berlatih di lingkungan akademis. Wilson dan Scalise (2006) mengatakan bahwa asesmen berpotensi untuk memperbaiki pembelajaran namun juga dapat menghambat pembelajaran. Wilson dan Scalise memberikan contoh tentang beberapa praktik pendidikan umum di perguruan tinggi.

Weurlander, et.al (2012) mengemukakan dua jenis asesmen formatif yang dipelajari adalah sebagai berikut: (1) penilaian tertulis individu dengan pertanyaan faktual terutama, dan (2) penilaian lisan yang mendorong siswa untuk memecahkan masalah dalam kelompok. Weurlander, et.al melakukan penelitian dengan mengambil data dengan mewawancari 70 mahasiswa jurusan Pathology di Karolinska Institute Swedia.

Asesmen formatif umumnya diakui bahwa penilaian sangat penting bagi pembelajaran siswa di pendidikan tinggi, dan umpan balik merupakan komponen inti dari proses penilaian dalam meningkatkan kinerja siswa (Charty, 2017). Miller (2009) menerapkan asesmen formatif berbasis komputer di Quenss University Canada. Miller menyatakan bahwa asesmen berbasis komputer (CBA) sudah menjadi paradigma baru dan menjadi tantangan menilai sejumlah besar siswa di program sarjana tahun pertama. Penyatuan teori penilaian formatif dan CBA telah menghasilkan instrumen penilaian baru yang berfokus pada pemberian umpan balik untuk mendukung pembelajaran mahasiswa sambil memanfaatkan kemajuan teknologi komputer.

Nicol dan Dick (2006) mengemukakan bahwa di pendidikan tinggi, asesmen formatif dan umpan balik masih dikontrol dan dipandang sebagai tanggung jawab dosen; dan umpan balik masih secara umum dikonseptualisasikan sebagai proses transmisi, meskipun beberapa peneliti berpengaruh baru-baru ini menantang sudut pandang ini. Umpan balik 'mengirim pesan' dosen kepada mahasiswa tentang apa yang benar dan salah dalam karya akademis mereka, tentang kekuatan dan kelemahannya, dan maha siswa menggunakan informasi ini untuk melakukan perbaikan selanjutnya.

Pastor dan Camacho (2016) memaparkan, literatur yang relevan menunjukkan adanya krisis dalam penerapan asesmen formatif di pendidikan tinggi karena tekanan pada pembelajaran dan pengajaran yang dialami saat ini dalam pendidikan saat ini. Diantara tekanan tersebut, Yorke (2003) menyoroti modifikasi dalam struktur kurikulum dan peningkatan standard bertujuan untuk 
meningkatkan hasil, meningkatnya rasio siswa di kelas, dan tekanan yang meningkat pada dosen untuk menghasilkan penelitian yang bertentangan dengan waktu yang mereka untuk mengajar.

Sharma (2015) berpendapat bahwa secara teoritis asesmen formatif cocok dilaksanakan pada pelatihan medis pasca sarjana karena melibatkan mahasiswa dan dosen secara bermakna dan kompleks. Di sisi lain, Gikanti menyatakan bahwa dalam asesmen formatif di pendidikan tinggi, dapat dilakukan asesmen formatif secara online, dimana pembelajaran online dan campuran telah menjadi tujuan umum strategi pendidikan di pendidikan tinggi.

Dari berbagai pendapat ahli tentang asesmen formatif di perguruan tinggi tersebut dapat disimpulkan bahwa asemen formatif merupakan bagian penting dalam pembelajaran/perkuliahan di perguruan tinggi. Penilaian dapat dilakukan dengan berbagai cara seperti berbasis program komputer dan menggunakan tablet. Di samping asesmen formatif secara offline, asesmen formatif juga dapat dilaksanakan secara online.

\section{METODE PENELITIAN}

Penelitian ini menggunakan desain Meta Analisis. Meta analisis secara sederhana dapat diartikan sebagai analisis atas analisis, dengan kata lain dalam meta analisis ini dilakukan analisis terhadap sejumlah analisis dari beberapa hasil penelitian tentang topik yang dipilih. Sebagai penelitian, meta analisis merupakan kajian atas sejumlah hasil penelitian dalam masalah yang sejenis. Instrumen dalam penelitian ini menggunakan Human Instrument. Setelah fokus penelitian menjadi jelas, maka akan dikembangkan instrumen penelitian sederhana, yang diharapkan dapat melengkapi data dan membandingkan kembali data yang telah ditemukan sebelumnya. Teknik pengumpulan data akan menggunakan teknik dokumentasi. Populasi dalam penelitian ini adalah semua dokumen tertulis mengenai penelitian asesmen formatif di Pendidikan Tinggi. Dokumen tertulis tersebut berupa artikel jurnal internasional sebanyak 15 jurnal. Sampel penelitian diambil menggunakan teknik Purposive Sampling. Hal ini dikarenakan data atau informasi yang ingin diperoleh dari sampel ditentukan berdasarkan kesesuaiannya dengan tema penelitian ini. Analisis data yang digunakan adalah analisis data kuantitatif dengan prosentase dan analisis data kualitatif untuk data-data hasil kajian naratif terhadap penelitian-penelitian yang ditemui.

\section{HASIL PENELITIAN}

Penelitian-penelitian tentang asesmen formatif di pendidikan tinggi yang didapatkan adalah sebanyak 15 penelitian. Seluruh jurnal yang dianalisis diperoleh dengan mengunduh dari internet.

\section{Meta Analisis Berdasarkan Tujuan Penelitian}

Tujuan-tujuan penelitian asesmen formatif di pendidikan tinggi menyajikan tentang penerapan asesmen formatif dan mengkaji seberapa penting asesemen formatif dilakukan dalam pembelajaran/perkuliahan. Berdasarkan kajian terhadap 15 jurnal dapat dihasilkan data sebagai berikut dalam tabel 2 berikut ini: 
Tabel 2. Tujuan Penelitian dalam Penelitian Asesmen Formatif di Pendidikan Tinggi

\begin{tabular}{|l|l|l|l|}
\hline No & Tujuan Penelitian & Frekuensi & Persentase \\
\hline 1 & $\begin{array}{l}\text { Mengembangkan dan meningkatkan } \\
\text { wawasan penilaian }\end{array}$ & 11 & 73,33 \\
\hline 2 & Mendeskripsikan & 2 & 13,33 \\
\hline 3 & Investigasi & 1 & 0,07 \\
\hline 4 & Critical Review & 1 & 0,07 \\
\hline & Jumlah & 15 & 100 \\
\hline
\end{tabular}

\section{Meta Analisis Berdasarkan Desain}

Penelitian-penelitian tentang asesmen formatif di pendidikan tinggi menggunakan beberapa desain penelitian, yaitu: eksperimen, survey, penelitian tindakan kelas dan deskriptif. Berdasarkan kajian terhadap 18 jurnal tentang asesmen formatif di pendidikan tinggi maka desain yang digunakan seperti terlihat dalam tabel 3 berikut ini:

Tabel 3. Desain Penelitian dalam Penelitian Asesmen Formatif di Pendidikan Tinggi

\begin{tabular}{|l|l|l|l|}
\hline No & Desain Penelitian & Frekuensi & Persentase \\
\hline 1 & Deskriptif & 11 & 73,33 \\
\hline 2 & Survey & 1 & 6,67 \\
\hline 3 & Eksploratori & 1 & 6,67 \\
\hline 4 & Eksperimen & 1 & 6,67 \\
\hline 5 & PTK & 1 & 6,67 \\
\hline & Jumlah & 15 & 100 \\
\hline
\end{tabular}

\section{Meta Analisis Berdasarkan Populasi/ sampel}

Populasi/sampel yang digunakan dalam penelitian-penelitian tentang asesmen formatif di pendidikan tinggi atau yang menjadi subjek penelitiannya adalah mahasiswa dari sejumlah perguruan tinggi, namun ada juga yang tidak melakukan pengambilan sampel karena jurnal yang terbit hanya berupa analisis literatur saja. Berdasarkan kajian terhadap 15 jurnal tentang asesmen formatif di pendidikan tinggi, maka orang yang dijadikan populas/ sampel dapat dilihat dalam tabel 4.

Tabel 4. Populasi/Sampel dalam Penelitian Asesmen Formatif di Pendidikan Tinggi

\begin{tabular}{|l|l|l|l|}
\hline No & Populasi/Sampel & Frekuensi & Persentase \\
\hline 1 & Mahasiswa & 7 & 46,67 \\
\hline 2 & Tidak Ada & 8 & 53,33 \\
\hline & Jumlah & 15 & 100 \\
\hline
\end{tabular}

\section{Meta Analisis Berdasarkan Metode/Teknik Pengumpulan Data}

Metode/teknik pengumpulan data yang digunakan dalam penelitian-penelitan tentang asesmen formatif di pendidikan tinggi antara lain: studi literatur, wawancara, kuesioner, portofolio dan survey. 
Berdasarkan kajian terhadap 15 penelitian tentang asesmen formatif di pendidikan tinggi, maka metode/teknik pengumpulan data yang digunakan dapat terlihat dalam tabel 5 berikut.

Tabel 5. Metode/Teknik Pengumpulan Data dalam Penelitian Asesmen Formatif di Pendidikan Tinggi

\begin{tabular}{|l|l|l|l|}
\hline No & Populasi/Sampel & Frekuensi & Persentase \\
\hline 1 & Studi literatur & 10 & 66,67 \\
\hline 2 & Wawancara & 1 & 6,67 \\
\hline 3 & Portofolio dan Kuesioner & 1 & 6,67 \\
\hline 4 & Survey & 1 & 6,67 \\
\hline 5 & Survey dan Kuesioner & 1 & 6,67 \\
\hline 6 & Wawancara dan Kuesioner & 1 & 6,67 \\
\hline & Jumlah & 15 & 100 \\
\hline
\end{tabular}

\section{Meta Analisis Berdasarkan Analisis Data}

Analisis yang digunakan pada penelitian yang termasuk pada meta analisis ini terdiri dari berbagai jenis analisis antara lain, deskriptif kualitatif, Deskriptif kuantitatif, dan ANOVA.

Tabel 6. Analisis Data dalam Penelitian Asesmen Formatif di Pendidikan Tinggi

\begin{tabular}{|l|l|l|l|}
\hline No & Populasi/Sampel & Frekuensi & Persentase \\
\hline 1 & Deskriptif Kualitatif & 12 & 46,67 \\
\hline 2 & Deskriptif Kuantitatif & 2 & 53,33 \\
\hline 3 & Deskriptif Kuantitatif dan ANOVA & 1 & 6,67 \\
\hline & Jumlah & 15 & 100 \\
\hline
\end{tabular}

Dari tinjauan hasil penelitian diketahui bahwa penelitian terhadap 15 jurnal yang tentang asesmen formatif di pendidikan tinggi pada umumnya, penelitian merupakan penelitian deskriptif yang bertujuan untuk meningkatkan wawasan dan mengembangkan asesmen terhadap kemampuan mahasiswa. Asesmen formatif yang dilakukan dilaksanakan di berbagai perguruan tinggi pada berbagai macam bidang keilmuan, seperti pendidikan bidang kesehatan, matematika dan lainnya. Sebagian besar peneliti memilih menggunakan studi literatur dalam penelitian tentang asesmen formatif, dan analisis yang digunakan pada umumnya secara deskriptif kualitatif. Penggunaan studi literatur ini membuat sebagian peneliti tidak melakukan pengambilan sampel.

Pada jurnal-jurnal yang terdapat dalam meta analisis ini, salah satu pokok pikiran yang dapat diambil yaitu asesmen formatif dinyatakan sebagai penilaian yang sangat bermanfaat dalam menilai kinerja mahasiswa. Asesmen formatif dipandang sebagai salah satu upaya untuk mengukur kemampuan mahasiswa sejak awal hingga akhir pembelajaran dan melibatkan mahasiswa di dalamnya. Seperti temuan penelitian Yorke (2010) bahwa dalam asesmen formatif, mahasiswa dapat bertindak seperti seorang manager yang dapat mempertimbangkan perkembangan kinerja mereka dalam mencapai kemampuan yang diharapkan. Weurlander, et.al (2011) mendeskripsikan asesmen 
formatif sebagai alat yang penting dalam mendorong tiga aspek dalam pembelajaran, antara lain memotivasi mahasiswa dalam belajar, dan membangkitkan kesadaran mahasiswa terhadap pembelajaran dan penilaian ini diharapkan berdampak baik terhadap proses maupun hasil pembelajaran.

Asesmen formatif bahkan dapat dilakukan dengan berbagai cara, seperti dengan cara manual yang dilakukan oleh Carthy (2017), dengan cara program CBA formatif seperti yang dilakukan oleh Miller (2009). Penilaian formatif di pendidikan tinggi dilakukan oleh Kowalski et.al (2009) dengan menggunakan PC tablet. Asesmen formatif dilakukan untuk berbagai tujuan, seperti yang disampaikan oleh Nel \& Kinnon (2014) bahwa responden dari USA melakukan penilaian formatif untuk mengembangkan kemampuan berfikir kritis dan kreatif untuk menghasilkan produk akhir, sedangkan di Afrika untuk memandu pencapaian hasil dalam menyelesaikan produk (tesis). Gikandi et.al (2001) melakukan asesmen formatif secara online untuk pembelajaran yang dilaksanakan dengan cara blended learning. Gikandi dalam temuan penelitiannya mengungkapkan bahwa asesmen formatif online dapat menyelaraskan penilaian dengan pengajaran dan pembelajaran.

\section{DAFTAR PUSTAKA}

Astuti, Astuti. Pengaruh Model Pembelajaran Kooperatif Tipe Two Stay Two Stray (Tsts) Terhadap Hasil Belajar Matematika Siswa Kelas Vii Smp Negeri 2 Bangkinang Kota. Jurnal Cendekia : Jurnal Pendidikan Matematika, [S.L.], N. 2, P. 11-28, Oct. 2016. Issn 2579-9258

Cruz, et.al. (2011). The Effect of Formative Assessment in Brazillian University Physic Courses

Dunn, K. E., \& Mulvenon, S. W. (2009). A Critical Review of Research on Formative Assessments: The Limited Scientific Evidence of the Impact of Formative Assessments in Education. Practical Assessment, Research \& Evaluation, 14(7), 1-11. https://doi.org/10.1002/ir

Friedrich-Nel, H., \& Mac Kinnon, J. (2015). Formative postgraduate assessment: a comparative case study using a university in the USA and one in South Africa. Innovations in Education and Teaching International, 52(6), 653-662. https://doi.org/10.1080/14703297.2014.981834

Gikandi, J. W., Morrow, D., \& Davis, N. E. (2011). Online formative assessment in higher education: A review of the literature. Computers and Education. https://doi.org/10.1016/j.compedu.2011.06.004

Kowalski, S. E., Kowalski, F. V., \& Gardner, T. Q. (2009). Lessons learned when gathering real-time formative assessment in the university classroom using tablet PCs. In Proceedings - Frontiers in Education Conference, FIE. https://doi.org/10.1109/FIE.2009.5350639

López-Pastor, V., \& Sicilia-Camacho, A. (2015). Formative and shared assessment in higher education. Lessons learned and challenges for the future. Assessment \& Evaluation in Higher Education, 2938(September 2015), 1-21. https://doi.org/10.1080/02602938.2015.1083535

McCarthy, J. (2017). Enhancing feedback in higher education: Students' attitudes towards online and in-class formative assessment feedback models. Active Learning in Higher Education, 18(2), 127-141. https://doi.org/10.1177/1469787417707615 
Miller, T. (2009). Formative computer- based assessment in higher education: the effectiveness of feedback in supporting student learning. Assessment \& Evaluation in Higher Education, 34(2), 181-192. https://doi.org/10.1080/02602930801956075

Nicol, D. J., \& Macfarlane- Dick, D. (2006). Formative assessment and self- regulated learning: a model and seven principles of good feedback practice. Studies in Higher Education, 31(2), 199218. https://doi.org/10.1080/03075070600572090

Sharma, S., Sharma, V., Sharma, M., Awasthi, B., \& Chaudhary, S. (2015). Formative assessment in postgraduate medical education - Perceptions of students and teachers. International Journal of Applied and Basic Medical Research, 5(4), 66. https://doi.org/10.4103/2229-516X.162282

Valencia, J., Macias, J., \& Valencia, A. (2015). Formative Research in Higher Education: Some Reflections. Procedia - Social and Behavioral Sciences, 176, 940-945. https://doi.org/10.1016/j.sbspro.2015.01.562

Weurlander, M., Söderberg, M., Scheja, M., Hult, H., \& Wernerson, A. (2012). Exploring formative assessment as a tool for learning: students' experiences of different methods of formative assessment. Assessment \& Evaluation in Higher Education, 37(6), 747-760. https://doi.org/10.1080/02602938.2011.572153

Wilson, M., \& Scalise, K. (2006). Assessment to improve learning in higher education: The BEAR Assessment System. Higher Education. https://doi.org/10.1007/s10734-004-7263-y

Yorke, M. (2003). Formative assessment in higher education: Moves towards theory and the enhancement of pedagogic practice. Higher Education, 45(4), 477-501. https://doi.org/10.1023/A:1023967026413

Yorke, M. (2005). Formative assessment in higher education: Its significance for employability, and steps towards its enhancement. Tertiary Education and Management, 11(3), 219-238. https://doi.org/10.1080/13583883.2005.9967148

Zulfah, Zulfah. Pengaruh Penerapan Model Pembelajaran Kooperatif Tipe Think Pair Share Dengan Pendekatan Heuristik Terhadap Kemampuan Pemecahan Masalah Matematis Siswa Mts Negeri Naumbai Kecamatan Kampar.Jurnal Cendekia : Jurnal Pendidikan Matematika, [S.L.], N. 2, P. 65-76, Mar. 2018. Issn 2579-9258.

Zulfah, Zulfah. Analisis Kesalahan Peserta Didik Pada Materi Persamaan Linear Dua Variabel Di Kelas Viii Mts Negeri Sungai Tonang. Jurnal Cendekia : Jurnal Pendidikan Matematika, [S.L.], V. 1, N. 1, P. 1-5, May 2017. Issn 2579-9258. 